\title{
Physiological limitations in two sugarcane varieties under water suppression and after recovering
}

\author{
David Barbosa Medeiros*, Elizamar Ciríaco da Silva², Rejane Jurema Mansur \\ Custódio Nogueira ${ }^{3}$, Marcelo Menossi Teixeira ${ }^{4}$, Marcos Silveira Buckeridge ${ }^{5}$
}

'Departamento de Agronomia, Universidade Federal Rural de Pernambuco, Recife, PE, Brazil.

${ }^{2}$ Laboratório de Botânica Aplicada, Departamento de Biologia, Universidade Federal de Sergipe, São Cristóvão, SE, Brazil.

${ }^{3}$ Laboratório de Fisiologia Vegetal, Departamento de Biologia, Universidade Federal Rural de Pernambuco, Recife, PE, Brazil.

${ }^{4}$ Laboratório de Genoma Funcional, Departamento de Genética, Evolução e Bioagentes, Instituto de Biologia, Universidade

Estadual de Campinas, Campinas, SP, Brazil.

${ }^{5}$ Laboratório de Fisiologia Ecológica de Plantas, Departamento de Botânica, Universidade de São Paulo, São Paulo, SP, Brazil.

*Corresponding author: davidmedeiros3@hotmail.com

Received: 17 January 2013; Accepted: 11 October 2013

ABSTRACT: Increasing water scarcity and depleted water productivity in irrigated soils are inducing farmers to adopt improved varieties, such as those with high-capacity tolerance. The use of tolerant varieties of sugarcane might substantially avoid the decline of productivity under water deficit. This research aimed to evaluate the harmful effects of drought on the physiology of two sugarcane varieties (RB867515 and RB962962) during the initial development. Young plants were subjected to irrigation suspension until total stomata closure, and then rewatered. Significant reduction on stomatal conductance, transpiration, and net photosynthesis were observed. RB867515 showed a faster stomatal closure while RB962962 slowed the effects of drought on the gas exchanges parameters with a faster recovering after rewatering. Accumulation of carbohydrates, amino acids, proline, and protein in the leaves and roots of the stressed plants occurred in both varieties, substantially linked to reduction of the leaf water potential. Due to the severity of stress, this accumulation was not enough to maintain the cell turgor pressure, so relative water content was diminished. Water stress affected the contents of chlorophyll ( $a, b$, and total) in both varieties, but not the levels of carotenoids. There was a significant reduction in dry matter under stress. In conclusion, RB962962 variety endured stressed conditions more than RB867515, since it slowed down the damaging effects of drought on the gas exchanges. In addition, RB962962 presented a faster recovery than RB867515, a feature that qualifies it as a variety capable of enduring short periods of drought without major losses in the initial stage of its development.

KEYWORDS: drought, photosynthesis, Saccharum spp, gas exchange.

\section{INTRODUCTION}

Drought is a major abiotic stress that impairs crop production worldwide, affecting growth rate and development (Begcy et al. 2012). As with others crops, the productivity of sugarcane, an important crop in Brazilian agro-industries due to its by-products such as sugar and ethanol, is highly dependent on water availability (Hemaprabha et al. 2004, Inman-Bamber 2004).

Water shortage is a result of climatic factors and is not restricted to arid regions. Even in humid regions, an inequality in the rainfall distribution causes limitations on plant growth
(Silva et al. 2013). Irrigation has been used to reduce the impact, making it possible for many crops to successfully grow.

Water is necessary for several metabolic reactions, and its restriction can affect all the aspects of growth and development in plants (Larcher 2006). The negative effects of water shortage over biochemical, physiological, and morphological processes can be verified in all parts of the plant. In situations of water restriction, common physiological alterations include reduced leaf water potential and the relative water content (Nogueira et al. 2000, Graça et al. 2010, 
Silva et al. 2010), gas exchange, photosynthesis, as well as reduced maximum quantum efficiency of the photosystem II (Inman-Bamber and Smith 2005, Silva et al. 2007, Jaleel et al. 2009, Gonçalves et al. 2010, Graça et al. 2010). As a consequence, metabolic changes such as increase in osmoregulators (Nogueira et al. 2001, Guimarães et al. 2008, Silva et al. 2009, Medeiros et al. 2012) may occur along with significant alterations on the plant growth, in response to the lower turgor pressure in the cells (Hessini et al. 2009).

Ways to improve sugarcane production and increase crop resilience are topics of intense investigation. With the outcome on sugarcane genome mapping, novel possibilities can appear such as genetic improvement assisted by molecular markers (Edwards and Batley 2010, Buckeridge et al. 2012, Ferreira et al. 2012, Gentile et al. 2013). Thus, physiological studies on sugarcane may identify varieties more tolerant to water stress and, ultimately, improve plant breeding.

Due to high genetic variability in sugarcane, the objective of the current study was to test the hypothesis that tolerance to drought in two high-production varieties of sugarcane is achieved by accumulation of organic solutes that allow the entrance of water, keeping the gas exchange for a longer period, reducing the losses in the initial stage of development.

\section{MATERIAL AND METHODS}

Plant material and growth conditions: The experiment was conducted in a greenhouse from January to May 2011. Average temperature and relative humidity during daylight ranged from $29.5-38.7^{\circ} \mathrm{C}$ and $25.0-55.0 \%$, respectively. Vapour pressure deficit (VPD) ranged from 1.9-5.1 kPa, and photosynthetic photon flux density (PPFD) ranged from 27.0 to $540.0 \mu \mathrm{mol} \mathrm{m}^{-2} \mathrm{~s}^{-1}$. These variations occurred, probably, due to intermittent cloudy and rainy days during the period of performing the experiment.

Field capacity (FC) was determined, as previously described by Souza et al. (2000), considering the difference between humid soil weight after saturation and free drainage, and the weight of air-dried soil. Maintenance of water treatments was made daily, by weighing the pots and replacing the volume of water lost by transpiration, using a precision scale with capacity for $20 \mathrm{~kg}$.

RB867515 and RB962962 varieties of sugarcane were selected because they possess high production rates, high levels of sucrose and medium levels of fibre (Simões Neto et al. 2005).

Seedlings were propagated vegetatively by simple cutting of the culm. Seedling transplant was performed $30 \mathrm{~d}$ after sowing. The most uniform plants based on the number of leaves, height, and healthy appearance were then transplanted into polyethylene pots containing $14 \mathrm{~kg}$ of soil. Physicochemical analysis of the soil is shown in Table 1.

Thirty days after transplant (acclimatization period), water treatments were initiated by maintaining the water suppression treatment plants without watering or by keeping the control treatment plants by watering on the field capacity.

At the time of first stomatal closure ( $4 \mathrm{~d}$ of stress exposure), half of both control and stressed plants (six plants) were harvested. And the remaining stressed plants by withholding of water were rewatered and the experiment continued until the total recovery of gas exchange was observed.

Gas exchange evaluation: Gas exchange parameters were measured, including stomatal conductance $\left(g_{\mathrm{S}}\right)$, transpiration $(\mathrm{E})$, and net photosynthesis $\left(\mathrm{A}_{\mathrm{N}}\right)$. The analyses were performed on leaf +1 (diagnostic leaf) by means of an infrared gas analyzer (IRGA), ADC model LCPro+, with an airflow of $300 \mathrm{~mL} \mathrm{~min}^{-1}$ and light source, coupled to a PPFD kept at $2000 \mu \mathrm{mol} \mathrm{m}^{-2} \mathrm{~s}^{-1}$, between 11:00 am and 1:00 pm, which is the period of highest transpiration to these varieties.

Table 1. Soil chemical and physical properties. The soil was collected in a deep of $0-200 \mathrm{~mm}$ from the Estação Experimental de Cana-de-Açúcar do Carpina - EECAC/UFRPE, localized in Carpina City, the North Forest Zone of Pernambuco State, Brazil

\begin{tabular}{|c|c|}
\hline Analysis & Soil depth (0-200 mm) \\
\hline \multicolumn{2}{|c|}{ Chemical } \\
\hline Electrical conductivity & $0.83 \mathrm{dS} \mathrm{m}^{-1}$ \\
\hline $\mathrm{pH}-\square$ & 4.0 \\
\hline $\mathrm{Ca}_{2}^{+}$ & $0.81 \mathrm{cmolc} \mathrm{kg}^{-1}$ \\
\hline $\mathrm{Mg}_{2}^{+}$ & $0.41 \mathrm{cmolc} \mathrm{kg}^{-1}$ \\
\hline $\mathrm{Na}^{+}$ & $0.32 \mathrm{cmolc} \mathrm{kg}^{-1}$ \\
\hline $\mathrm{N}$ & $1.80 \mathrm{~g} \mathrm{~kg}^{-1}$ \\
\hline $\mathrm{P}$ & $41 \mathrm{mg} \mathrm{kg}^{-1}$ \\
\hline $\mathrm{K}^{+}$ & $0.06 \mathrm{cmolc} \mathrm{kg}^{-1}$ \\
\hline $\mathrm{Al}_{3}^{+}+$ & $3.10 \mathrm{cmolc} \mathrm{kg}^{-1}$ \\
\hline Organic matter & $38.27 \mathrm{~g} \mathrm{~kg}^{-1}$ \\
\hline \multicolumn{2}{|c|}{ Physical } \\
\hline Total porosity & $45 \%$ \\
\hline Bulk density & $1.42 \mathrm{~g} \mathrm{~cm}^{3}$ \\
\hline Real density & $2.58 \mathrm{~g} \mathrm{~cm}^{3}$ \\
\hline Sand & $69.1 \%$ \\
\hline Silt & $10.4 \%$ \\
\hline Clay & $20.5 \%$ \\
\hline Textural classification & Franco sandy clay \\
\hline \multicolumn{2}{|c|}{ Moisture retention curve } \\
\hline Moisture at $1.5 \mathrm{MPa}$ & $14 \%$ \\
\hline Moisture at $0.03 \mathrm{MPa}$ & $18.9 \%$ \\
\hline Useful water & $4.9 \%$ \\
\hline
\end{tabular}


Soluble carbohydrate, free amino acids, free proline, and soluble proteins contents: One gram of fresh leaves $($ leaf +2$)$ and fresh root were collected during the first stomatal closure, which was 4 days after stress exposure (DSE), to evaluate the effects of drought and, at the end of the experiment (6 days after rewatering - DAR to RB867515 and 2 DAR to RB962962) to evaluate the effects of rewatering. Samples were stored at $-20^{\circ} \mathrm{C}$ prior to preparation of extracts.

Extracts were prepared by grinding up plant tissue with $4 \mathrm{~mL}$ (to leaves) and $5 \mathrm{~mL}$ (to roots) of $0.1 \mathrm{M}$ monobasic phosphate buffer ( $\mathrm{pH} 7.0)$. The homogenate was filtered and centrifuged to $14,676 \mathrm{xg}$ for $15 \mathrm{~min}$ at $4{ }^{\circ} \mathrm{C}$. The supernatant was utilized for further analyses. Total soluble carbohydrates were determined using the phenol-sulphuric acid method with $\mathrm{D}(+)$-glucose as the standard (Dubois et al. 1956). Free amino acids were analyzed using the ninhydrin method with L-leucine as the standard (Yemm and Cocking 1955). Free proline concentration was determined using the ninhydrin and phosphoric acid method with proline as the standard (Bates 1973). Soluble protein concentration was determined using the protein dye binding method with bovine serum albumin (BSA) as the standard (Bradford 1976). Final measurement of carbohydrates, free proline, free amino acids, and soluble protein were carried out using a spectrophotometer at wavelengths $490,520,570$, and $595 \mathrm{~nm}$, respectively.

\section{Water potential and relative water content} measurements: Measurements of leaf water potential $\left(\Psi_{\mathrm{w}}\right)$ and relative water content (RWC) were carried out at 4:00 am on the first day after the first stomatal closure (4 DSE). Leaf +1 was utilized for $\Psi_{w}$ determinations that were made with a pressure chamber (Model 3035, Soil Moisture Equipment Corp., CA, USA), according to Scholander et al. (1964).

RWC was determined in six discs obtained from the leaf blade of the same leaves utilized for $\Psi_{w^{\prime}}$ which were immediately weighed to obtain the fresh mass weight (FMW). The leaves were put into a petri dish with filter paper soaked with $10 \mathrm{~mL}$ deionized water and left in the refrigerator for $24 \mathrm{~h}$. The discs were then weighed to obtain the turgid mass weight (TMW). Finally, the discs were dried in an oven at $65^{\circ} \mathrm{C}$ for $48 \mathrm{~h}$ to obtain the dry mass weight (DMW). According to Barrs and Weatherley (1962), RWC was calculated using the following formula: RWC $=[($ FMW - DMW $) /($ TMW - DMW $)] \times 100 \%$.

\section{Chlorophyll a fluorescence and photosynthetic} pigments measurements: For the first stomatal closure (4 DSE), at 12:00 pm, the emission of chlorophyll a fluorescence was evaluated through a modulated fluorometer (Opti-Sciences, model Os30p+, Hudson, USA), from which was obtained the initial fluorescence $\left(\mathrm{F}_{0}\right)$, the maximum fluorescence $\left(\mathrm{F}_{\mathrm{m}}\right)$, and the maximum quantum efficiency of the photosystem II $\left(\mathrm{F}_{\mathrm{v}} / \mathrm{F}_{\mathrm{m}}\right)$, after dark adaptation of the leaves (leaf +2 ) for 30 min with leafclips. To determine $\mathrm{F}_{0^{\prime}}$ a weak measuring light was turned on and $\mathrm{F}_{0}$ was recorded. The leaves were then exposed to a saturated flash of approximately $6000 \mu \mathrm{mol} \mathrm{m} \mathrm{s}^{-1}$ to obtain $\mathrm{F}_{\mathrm{m}}$. The $\mathrm{F}_{\mathrm{v}} / \mathrm{F}_{\mathrm{m}}$ ratio was automatically calculated based on $\mathrm{F}_{0}$ and $\mathrm{F}_{\mathrm{m}}$ using the following formula: $\mathrm{F}_{\mathrm{v}} / \mathrm{F}_{\mathrm{m}}=\left(\mathrm{F}_{\mathrm{m}}-\mathrm{F}_{0}\right) / \mathrm{F}_{\mathrm{m}}$.

The levels of chlorophyll $a, b$, and carotenoids were quantified utilizing $0.1 \mathrm{~g}$ of fresh leaves (leaf +2 ), which were ground and soaked in $10 \mathrm{~mL}$ of $80 \%$ acetone for $48 \mathrm{~h}$ under refrigeration and protected from light. Chlorophyll $a$, $b$, and carotenoids were measured in a spectrophotometer at a wavelength of 663,647 , and $470 \mathrm{~nm}$, respectively. The levels of total chlorophyll $a, b$, and carotenoids were then calculated as described by Lichtenthaler and Buschmann (2001), and expressed in $\mathrm{mg} \mathrm{g}^{-1} \mathrm{FM}$.

Dry mass production: To evaluate the effects of drought on growth in the first stomatal closure (4 DSE), plants were collected and separated into shoot and roots. Shoot dry mass (SDM), root dry mass $(\mathrm{RDM})$, and total dry mass (TDM) were determined after drying the plant tissues in an oven at $65^{\circ} \mathrm{C}$ for $6 \mathrm{~d}$.

Experimental design and statistical analysis: The experimental design was completely randomized in a split-plot scheme using two sugarcane varieties (RB867515 and RB962962) and three water treatments (control, water suppression, and rewatering) with six replicates per treatment.

Analysis of variance (ANOVA) and comparison of averages by a Tukey's Multiple Range test $(\mathrm{p}<0.05)$ were performed using ASSISTAT 7.5 software.

\section{RESULTS}

Gas exchanges: The behaviour of $g_{\mathrm{S}}, \mathrm{E}$, and $\mathrm{A}_{\mathrm{N}}$ were similar during stress, as shown in Figure 1. Thus, the $g_{\mathrm{S}}$ of the RB867515 variety reduced $100 \%$ in the water suppression treatment compared to the control at 4 DSE, which was observed at the closure of the stomata. The total recuperation of $g_{\mathrm{S}}$ was confirmed on 4 DAR. In the RB962962 variety, reductions were verified at the 2 DSE, 6 DSE, and 8 DSE (the time of stomatal closure) of 35,91 , and $96 \%$, respectively. The recuperation of the $g_{S}$ values at 2 DAR was also verified.

The $E$ in the RB867515 variety, underwent significant reductions of $98.8 \%$ at 4 DSE, having recovery of the values on the stressed treatment at 2 DAR. The RB962962 variety underwent reductions at 6 DSE and 8 DSE of 75.1 and $93.3 \%$, respectively, and total recuperation of the $g_{S}$ was observed at $2 \mathrm{DAR}$. 


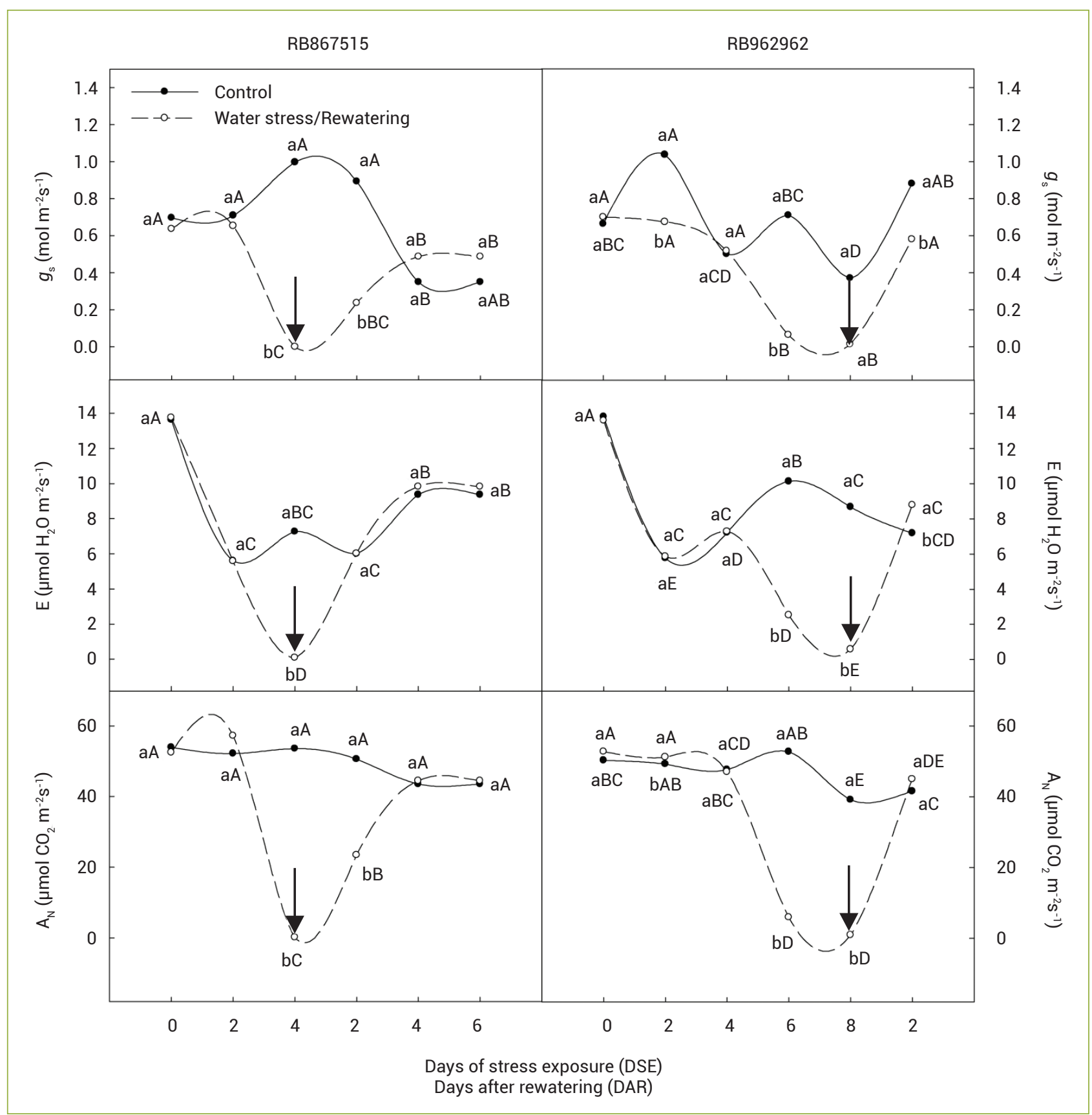

Figure 1. Stomatal conductance $\left(g_{S}\right)$, transpiration $(E)$, and net photosynthesis $\left(A_{N}\right)$ of two sugarcane varieties under drought and after rewatering in greenhouse conditions. Arrows indicate the rewatering day. Equal letters, lower case between treatments and upper case among time of evaluate, do not significantly differ by Tukey's Multiple Range test $(p<0.05)$.

To $A_{\mathrm{N}}$ analysis, reduction of $99.6 \%$ on the water suppression treatment in RB867515 was observed at 4 DSE when compared to the control treatment, with average values of $0.19 \mu \mathrm{mol} \mathrm{CO} \mathrm{m}^{-2} \mathrm{~s}^{-1}$ and $53.54 \mu \mathrm{mol} \mathrm{CO} \mathrm{m}^{-2} \mathrm{~s}^{-1}$ for the treated and the control, respectively. After rewatering, a recovery was observed only on the fourth subsequent day. For the RB962962 variety, photosynthetic restriction only occurred at $8 \mathrm{DSE}$, in which the treatment without watering presented average values of $0.89 \mu \mathrm{mol} \mathrm{CO} \mathrm{m}^{-2} \mathrm{~s}^{-1}$ with reductions of $97.7 \%$ compared to the control. At $2 \mathrm{DAR}$, recovery was observed in this variety with values around $50 \mu \mathrm{mol} \mathrm{CO} \mathrm{m}^{-2} \mathrm{~s}^{-1}$.

Chlorophyll $a, b$, total, and carotenoids contents and chlorophyll a fluorescence: Drought caused similar 
reductions in chlorophyll $a, b$, and total, in both RB867515 and RB962962, averaging 21.6 and $17.9 \%$ respectively (Table 2). Regarding carotenoids, no significant differences were observed in response to stress. Specifically, average levels were of 0.20 and $0.23 \mathrm{mg} \mathrm{g}^{-1} \mathrm{FM}$ for RB867515 and RB962962, respectively.

Despite reduction in the levels of chlorophyll $a$, lack of water did not cause alterations in the fluorescence (Table 3).

\section{Soluble carbohydrate, free amino acids, free proline,} and soluble proteins: Similar behaviours were observed in both the varieties under study. On the leaves of both varieties, there was an increase in osmoregulators upon stress treatment (Table 4). After rewatering, these values returned to normal levels, in the carbohydrates content of the RB962962 variety, which did not differ of the water suppression and control treatment, such as in the RB867515 variety that did not differ of the water suppression treatment. Therefore, in the plant under water suppression, the increase of carbohydrates, amino acids, proline, and protein were $51.2,23.5,81.2$, and $27 \%$ on the RB867515 variety and $28,51.1,72$, and $31.8 \%$ on the RB962962 variety, respectively, compared to control plants.

Alterations in the levels of osmoregulators in the roots were similar to the leaves (Table 5), increasing significantly in the plants without irrigation, yet decreasing in the rewatered plants. Carbohydrates, amino acids, proline, and proteins increased by $85,85.8,70$, and $71.1 \%$, respectively, in RB867515, and 43.6, $86.3,70.7$, and $71.7 \%$, respectively, in RB962962.

Table 2. Photosynthetic pigments content in $\mathrm{mg} \mathrm{gFM}^{-1}$ of two sugarcane varieties under drought and after rewatering in greenhouse conditions

\begin{tabular}{|c|c|c|c|c|}
\hline \multirow{2}{*}{ Treatments } & \multicolumn{2}{|c|}{ Chl a } & \multicolumn{2}{|c|}{ Chl $b$} \\
\hline & RB867515 & RB962962 & RB867515 & RB962962 \\
\hline Control & $1.05 \mathrm{aA}$ & $1.09 \mathrm{aA}$ & $0.30 \mathrm{aA}$ & $0.34 \mathrm{aA}$ \\
\hline Water suppression & $0.81 \mathrm{bA}$ & $0.89 \mathrm{bA}$ & $0.24 \mathrm{bA}$ & $0.28 \mathrm{bA}$ \\
\hline \multirow{2}{*}{ Treatments } & \multicolumn{2}{|c|}{ Chl total } & \multicolumn{2}{|c|}{ Carotenoids } \\
\hline & RB867515 & RB962962 & RB867515 & RB962962 \\
\hline Control & $1.35 \mathrm{aA}$ & $1.44 \mathrm{aA}$ & $0.21 \mathrm{aA}$ & $0.24 \mathrm{aA}$ \\
\hline Water suppression & $1.05 \mathrm{bA}$ & $1.18 \mathrm{bA}$ & $0.19 \mathrm{aA}$ & $0.22 \mathrm{aA}$ \\
\hline
\end{tabular}

Identical letters, lower case among treatments and upper case between varieties, do not significantly differ by Tukey's Multiple Range test $(p<0.05)$.

Table 3. Chlorophyll fluorescence of two sugarcane varieties under drought and after rewatering in greenhouse conditions

\begin{tabular}{|c|c|c|c|c|}
\hline \multirow{2}{*}{ Treatments } & \multicolumn{2}{|c|}{$F_{0}$} & \multicolumn{2}{|c|}{$F_{v}$} \\
\hline & RB867515 & RB962962 & RB867515 & RB962962 \\
\hline Control & $43.00 \mathrm{aB}$ & $51.25 \mathrm{aA}$ & $177.00 \mathrm{aA}$ & $164.00 \mathrm{aA}$ \\
\hline Water suppression & $47.25 \mathrm{aA}$ & $49.00 \mathrm{aA}$ & $165.25 \mathrm{aA}$ & $151.25 \mathrm{aA}$ \\
\hline \multirow{2}{*}{ Treatments } & \multicolumn{2}{|c|}{$F_{m}$} & \multicolumn{2}{|c|}{$F_{v} / F_{m}$} \\
\hline & RB867515 & RB962962 & RB867515 & RB962962 \\
\hline Control & $220.00 \mathrm{aA}$ & $215.25 \mathrm{aA}$ & $0.80 \mathrm{aA}$ & $0.76 \mathrm{aB}$ \\
\hline Water suppression & $212.50 \mathrm{aA}$ & $200.25 \mathrm{aA}$ & $0.78 \mathrm{aA}$ & $0.75 \mathrm{aA}$ \\
\hline
\end{tabular}

$F_{0}=$ minimum fluorescence; $F_{V}=$ variable fluorescence; $F_{M}=$ maximum fluorescence; $F_{v} / F_{M}=$ maximum quantum yield of photosystem II.

Identical letters, lower case among treatments and upper case between varieties, do not significantly differ by Tukey's Multiple Range test $(p<0.05)$.

Table 4. Soluble carbohydrate, free amino acids, free proline, and soluble proteins contents ( $\left.\mu \mathrm{mol} \mathrm{g} \mathrm{FM}^{-1}\right)$ in the leaves of two sugarcane varieties under drought and after rewatering in greenhouse conditions

\begin{tabular}{|c|c|c|c|c|}
\hline \multirow{2}{*}{ Treatments } & \multicolumn{2}{|c|}{ Carbohydrate } & \multicolumn{2}{|c|}{ Amino acids } \\
\hline & RB867515 & RB962962 & RB867515 & RB962962 \\
\hline Control & $47.7 \mathrm{bA}$ & $66.9 \mathrm{bA}$ & $12.7 \mathrm{abA}$ & $14.8 \mathrm{bA}$ \\
\hline Water suppression & $97.7 \mathrm{aA}$ & $92.9 \mathrm{aA}$ & $16.6 \mathrm{aB}$ & $30.3 \mathrm{aA}$ \\
\hline Rewatering & 89.4 aA & $79.7 \mathrm{abA}$ & $10.3 \mathrm{bA}$ & $12.2 \mathrm{bA}$ \\
\hline \multirow{2}{*}{ Treatments } & \multicolumn{2}{|c|}{ Proline } & \multicolumn{2}{|c|}{ Proteins } \\
\hline & RB867515 & RB962962 & RB867515 & RB962962 \\
\hline Control & $0.16 \mathrm{bA}$ & $0.21 \mathrm{bA}$ & $519.8 \mathrm{bA}$ & $462.5 \mathrm{bA}$ \\
\hline Water suppression & $0.85 \mathrm{aA}$ & $0.75 \mathrm{aA}$ & $712.49 \mathrm{aA}$ & $678.7 \mathrm{aA}$ \\
\hline Rewatering & $0.16 \mathrm{bA}$ & $0.21 \mathrm{bA}$ & $530.8 \mathrm{bA}$ & $363.0 \mathrm{bB}$ \\
\hline
\end{tabular}

Identical letters, lower case among treatments and upper case between varieties, do not significantly differ by Tukey's Multiple Range test $(\mathrm{p}<0.05)$. 
Water potential and relative water content: The $\Psi$ (Figure 2) presented similar changes in both varieties with significant reductions during stress treatment and values around 11-fold times smaller than those found in the control treatment, on average - 1.19 and $-0.78 \mathrm{MPa}$ in the RB867515 and the RB962962 varieties, respectively. On rewatering treatment, a recovery of the plant water status was observed, as expected, with no difference among treatments, the average values of that treatment were $-0.16 \mathrm{MPa}$ in the RB867515 variety and $-0.14 \mathrm{MPa}$ in the RB962962 variety.
Due to reduction of water in the soil, RWC decreased significantly (Figure 2) with average values of 88.7 and $90.7 \%$ in the RB867515 and RB962962 varieties, respectively. After rewatering treatment in RB867515, there were no statistical differences compared to the control treatment. However, a $4.5 \%$ difference was observed in RB962962.

Dry mass production: Dry mass production (Table 6) decreased only in the RB867515 variety in shoot and roots in response to drought. Observed decreases were 32.2, 55.2,

Table 5. Soluble carbohydrate, free amino acids, free proline, and soluble proteins contents ( $\mu \mathrm{mol} \mathrm{g} \mathrm{FM}^{-1}$ ) in roots of two sugarcane varieties under drought and after rewatering in greenhouse conditions

\begin{tabular}{|c|c|c|c|c|}
\hline \multirow{2}{*}{ Treatments } & \multicolumn{2}{|c|}{ Carbohydrate } & \multicolumn{2}{|c|}{ Amino acids } \\
\hline & RB867515 & RB962962 & RB867515 & RB962962 \\
\hline Control & 24.0 bB & $75.9 \mathrm{bA}$ & $8.0 \mathrm{bA}$ & 8.1 bA \\
\hline Water suppression & $160.5 \mathrm{aA}$ & $134.7 \mathrm{aB}$ & $56.4 \mathrm{aA}$ & $59.5 \mathrm{aA}$ \\
\hline Rewatering & $13.4 \mathrm{bB}$ & $77.3 \mathrm{bA}$ & $8.8 \mathrm{bA}$ & $11.0 \mathrm{bA}$ \\
\hline \multirow{2}{*}{ Treatments } & \multicolumn{2}{|c|}{ Proline } & \multicolumn{2}{|c|}{ Proteins } \\
\hline & RB867515 & RB962962 & RB867515 & RB962962 \\
\hline Control & 0.18 bA & $0.17 \mathrm{bA}$ & $73.7 \mathrm{cA}$ & $62.0 \mathrm{cA}$ \\
\hline Water suppression & $0.60 \mathrm{aA}$ & $0.58 \mathrm{aA}$ & $255.4 \mathrm{aA}$ & $219.3 \mathrm{aB}$ \\
\hline Rewatering & $0.17 \mathrm{bA}$ & $0.12 \mathrm{bA}$ & $115.9 \mathrm{bA}$ & $115.1 \mathrm{bA}$ \\
\hline
\end{tabular}

Identical letters, lower case among treatments and upper case between varieties, do not significantly differ by Tukey's Multiple Range test $(p<0.05)$.

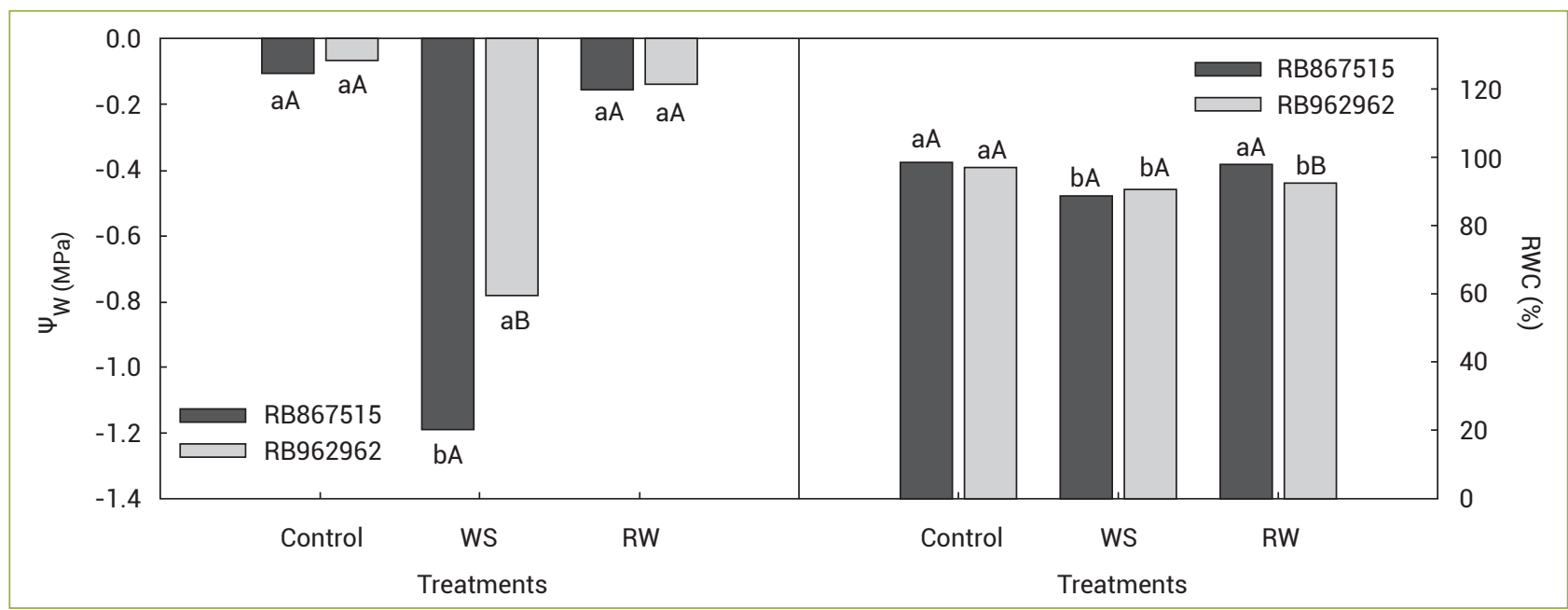

Figure 2. Predawn leaf water potential $\left(\Psi_{w}\right)$ and relative water content (RWC) of two sugarcane varieties under drought and after rewatering in greenhouse conditions. WS: water stress; RW: rewatering. Identical letters, lower case among treatments and upper case between varieties, do not significantly differ by Tukey's Multiple Range test $(p<0.05)$.

Table 6. Dry mass production of two sugarcane varieties under drought in greenhouse conditions

\begin{tabular}{lcccccc} 
& \multicolumn{3}{c}{ SDM $(\mathrm{g})$} & \multicolumn{2}{c}{ RDM $(\mathrm{g})$} & \multicolumn{2}{c}{ TDM (g) } \\
\cline { 2 - 7 } Treatments & RB867515 & RB962962 & RB867515 & RB962962 & RB867515 & RB962962 \\
Control & $6.33 \mathrm{aA}$ & $5.14 \mathrm{aA}$ & $17.40 \mathrm{aA}$ & $7.35 \mathrm{aB}$ & $23.72 \mathrm{aA}$ & $12.49 \mathrm{aB}$ \\
Water suppression & $4.29 \mathrm{bA}$ & $3.90 \mathrm{aA}$ & $7.80 \mathrm{bA}$ & $7.17 \mathrm{aA}$ & $12.09 \mathrm{bA}$
\end{tabular}

SDM: Shoot Dry Mass; RDM: Root Dry Mass; TDM: Total Dry Mass.

Identical letters, lower case among treatments and upper case between varieties, do not significantly differ by Tukey's Multiple Range test ( $\mathrm{p}<0.05$ ). 
and $49.0 \%$ for dry mass of shoot, root, and total, respectively. Interestingly, under suitable water conditions, RB867515 produced more dry mass than RB962962 with values of total dry mass being $47.3 \%$ higher.

\section{DISCUSSION}

When plants are subjected to water stress, gas exchange between the leaf and the atmosphere generally decreases. This reduces the water vapour dissipation due to the closure of stomata, and causes a reduction of atmospheric $\mathrm{CO}_{2}$ fixation, essential to photosynthetic reactions, as observed in the present study, when $g_{S}$ reduced close to zero at 4 DSE in RB867515 and at 8 DSE in RB962962, with consequent decrease in $E$ and $A_{\mathrm{N}}$ (Figure 1). These results are similar to those found to Graça et al. (2010) for the cultivars CTC15 (four days) and SP83-2847 and SP86-155 (seven days of withholding water). Thus, stomatal closure may be the first response to drought in RB867515 to minimize water losses, once this variety reduced $g_{s}$ and $E$ faster than RB962962. In other words, such results could demonstrate the sensitivity of RB867515 to water deficit.

High relative humidity and cloudy weather observed on the second day of evaluation significantly affected overall transpiration, including the control treatment. The $A_{\mathrm{N}^{\prime}}$ however, was not reduced at this period, which should be explained by photosynthetic pathway of sugarcane (C4) that allows this species to maintain favourable photosynthesis rates even with small stomatal opening (Larcher 2006).

The full gas exchange recovery after rewatering was different between sugarcane varieties. Thus, while the recovery of RB962962 occurred at 2 DAR, the recovery of RB867515 was observed only at $4 \mathrm{DAR}$. The fast recovery exhibited by RB962962 is an important feature of drought tolerance and, perhaps, increases the survival and cell damage repair after the stress period. It is important to mention that the interval between stress imposition and plant recovery as well as physiological responses are dependent on the plant species and varieties, the parameters, and the water deficit level (Liberato et al. 2006, Souza et al. 2004).

Some studies on the effects of water deficit on the photosynthetic pigments in sugarcane have been reported (Cha-um and Kirdmanee 2009, Jangpromma et al. 2010, Cha-um et al. 2012). According to Jaleel et al. (2009), water deficit usually reduces chlorophyll content and induces changes in the chlorophyll $a / b$ ratio and carotenoids. However, even though the destruction of pigments due to oxidative damage is common in plants exposed to severe water stress, plants synthesize antioxidants (carotenoids, ascorbate, $a$-tocopherol, glutathione, and flavonoids) to protect themselves (Ejert and Tevini 2002) concomitantly with the increasing activity of antioxidant enzymes (peroxidases, superoxide dismutase, and catalases). These assertions corroborate with this study since reductions were observed in the treated plants for chlorophyll, but not to carotenoids. This demonstrates, possibly, an attempt on minimizing damages to the photosynthetic apparatus due to imposed stress.

Despite reduction in the levels of chlorophyll $a$, drought did not cause reductions in the fluorescence variables, justifying the maintenance of the level of carotenoids, which are known as protectors against oxidative damage on photosystem II. Gonçalves et al. (2010) reported changes on the photochemical efficiency of photosystem II on sugarcane varieties, where the authors observed a reduction of chlorophyll a fluorescence from plants submitted to $20 \%$ of field capacity. This reduction was expressive for SP791011, RB72454, and RB98710, except for RB92579, showing that the radiation intercepted by this variety was used in the photochemical phase of photosynthesis, with no damage of photosystem II under drought stress. According to Silva et al. (2007), keeping $\mathrm{F}_{\mathrm{v}} / \mathrm{F}_{\mathrm{m}}$ values under water stress similar to those values in plants under suitable water conditions indicates high efficiency on the use of radiation, possibly by the reactions of carbon assimilation.

Under adverse growth conditions, plants adopt physiological and metabolic control for their survival. Under drought, this control seeks to balance the water inlet and outlet to maintain the cell turgor. The accumulation of osmoregulators in response to drought is an important mechanism for maintaining cell turgor, contributing to alleviate the reduction of the water potential. Previous studies have observed an increase in solutes in sugarcane and other species under water-deficient conditions (Ashraf and Foolad 2007, Cha-um e Kirdmanee 2009, Silva et al. 2009, Silva et al. 2013). Nevertheless, only solute accumulation does not favour the tolerance to drought per se, but the pathway that leads to the mechanism of drought tolerance is strongly influenced by this factor (Hasegawa et al. 2000, Medeiros et al. 2012). In this study, increments on the concentration of all osmoregulators evaluated in both the varieties under study were observed, and proteins were the major contributors to the osmoregulation of those varieties. Alternatively, the analysis of organic solutes in the leaves and roots of stressed plants after rewatering was similar to control plants, suggesting that the accumulation of those compounds in leaves and roots of the stressed plants was an important mechanism for osmoprotection and osmoregulation during drought conditions.

Increase in soluble carbohydrate content may occur at the beginning of stress as a result of growth cessation and 
by the intensity of water deficit, due to starch degradation (Pimentel 1999, Sircelj et al. 2005, Medeiros et al. 2012). In the present study, soluble carbohydrates increased in leaves and roots likely due to growth interruption (Table 6).

The synthesis of free amino acids is also affected by drought. Recent studies indicate that the main function of amino acid accumulation may be related to the osmotic adjustment (Sircelj et al. 2005, Silva et al. 2009, Medeiros et al. 2012). In the present work, increases were observed in amino acid concentrations in the water suppression treatment, what may attest the function of osmoregulation and/or osmoprotection of these compounds. It is also important to point out that the increase in amino acid levels was not due to proteolysis since, in this study, no reduction in soluble proteins was observed, but increases as a function of the stress imposed.

Free proline content generally increased due to water stress in the present work in the leaves and roots in both varieties of sugarcane. Such a situation was observed in other sugarcane varieties also (Queiroz et al. 2008, Cha-um and Kirdmanee 2009). According to Ashraf and Foolad (2007), the accumulation of proline is the first response of plants exposed to water stress in order to reduce injuries to the cells. The important role of proline to drought tolerance assisting in osmotic adjustment (Kavi Kishor et al. 2005), stabilizing the membrane and eliminating oxygen radicals, and preventing damage to cell structures caused by environmental stresses is a matter of study (Ashraf and Foolad 2007; Silva et al. 2013).

Accumulation of organic solutes, mainly in the roots, has an important role in maintaining the soil water available for the roots, thereby helping to keep the cell turgor. Although substantial increases have occurred on the osmoregulators levels, plants were not able to maintain their cells with optimum turgor under drought, and as a result, cessation of growth and leaf dehydration was observed (Figure 2). The $\Psi_{w}$ and RWC on predawn confirmed the low level of cell turgor, presenting lower values on the stressed plants when compared to control and rewatering. The $\Psi_{\mathrm{w}}$ predawn is known as the most sensitive variable when evaluating water stress in plants, because

\section{REFERENCES}

Ashraf M, Foolad MR (2007) Roles of glycine betaine and proline in improving plant abiotic stress resistance. Environmental and Experimental Botany 59:206-216.

Barrs HD, Weatherley PE (1962) A re-examination of the relative turgidity technique for estimating water deficit in leaves. Australian Journal of Biological Science 15:413-428.

Bates LS (1973) Rapid determination of free proline for water-stress studies. Plant Soil 39:205-207. transpiration does not occur at predawn (Sircelj et al. 2005). Thus, the accumulation of organic solutes, although necessary to maintain the turgor, could be a result of the reduction in the relative water content on the tissue, which tends to concentrate the cell contents.

It is well established that water deficit affects both plant growth and development (Lawlor 2013). Despite the short time between stopping irrigation and rewatering, a sequence of events leading to reductions of dry mass production in both shoots and roots was observed only in stressed plants of the RB867515 variety. It is worth noting that under appropriate water availability, this variety has a faster vegetative development. The decrease in dry mass observed in RB867515 plants during drought stress may be explained, at least partially, due to the both lower $g_{s}$ and reduced apparent carboxylation efficiency. Altogether, these results, coupled with the maintenance of biomass production, even with reductions in gas exchanges, observed in RB962962 plants, indicate that this variety has a higher drought tolerance in comparison with RB867515.

In summary, the varieties of sugarcane studied alter development when subjected to drought, modifying both physiology and metabolism. Specifically, gas exchange was reduced and organic solute concentrations were increased, reducing their water potential to maintain cell turgor. RB962962 was more tolerant than RB867515, because it could slow down the damaging effects of drought on gas exchange, what did not cause significant losses in dry matter production. Moreover, after rewatering, RB962962 was able to recover faster than RB867515, a characteristic that qualifies this variety to support short periods of drought without major losses in the initial phase of its development.

\section{ACKNOWLEDGMENTS}

The authors would like to thank the INCT do Bioetanol/ $\mathrm{CNPq}$ for financial support, as well as the Estação Experimental de Cana-de-Açúcar do Carpina - EECAC/UFRPE for plant material and soil. We would like to thank Hugo Bentzen (UFRPE) for technical support and Wagner Araújo (Universidade Federal de Viçosa) for suggestions.

Begcy K, Mariano ED, Gentile A, Lembke CG, Zingaretti SM, Souza GM, Menossi M (2012) A novel stress-induced sugarcane gene confers tolerance to drought, salt and oxidative stress in transgenic tobacco plants. PLoS One 7:e44697.

Bradford MM (1976) A rapid and sensitive method for the quantitation of microgram quantities of protein utilizing the principle of protein-dye binding. Analytical Biochemistry 72:248-250. 
Buckeridge MS, Souza AP, Arundale RA, Kristina J. Anderson-Teixeira KJ, Delucia E (2012) Ethanol from sugarcane in Brazil: a 'midway' strategy for increasing ethanol production while maximizing environmental benefits. Global Change Biology Bioenergy 4:119-126.

Cha-um S, Kirdmanee C (2009) Effect of osmotic stress on proline accumulation, photosynthetic abilities and growth of sugarcane plantlets (Saccharum officinarum L.). Pakistan Journal of Botany 40:2541-2552.

Cha-um S, Wangmoon S, Mongkolsiriwatana C, Ashraf M, Kirdmanee C (2012) Evaluating sugarcane (Saccharum sp.) cultivars for water deficit tolerance using some key physiological markers. Plant Biotechnology 29:431-439.

Dubois M, Gilles KA, Hamilton JK, Rebers PA, Smith F (1956) Colorimetric method for determination of sugars and related substances. Analytical Chemistry 28:350-356.

Edwards D, Batley E (2010) Plant genome sequencing: applications for crop improvement. Plant Biotechnology Journal 8:2-9.

Egert M, Tevini M (2002) Influence of drought on some physiological parameters symptomatic for oxidative stress in leaves of chives (Allium schoenoprasum). Environmental and Experimental Botany 48:43-49.

Farooq M, Wahid A, Kobayashi N, Fujita D, Basra SMA (2009) Plant drought stress: effects, mechanisms and management. Agronomy for Sustainable Development 29:185-212.

Ferreira TH, Gentile A, Vilela RD, Costa GGL, Dias LI, Endres L, Menossi M (2012) microRNAs associated with drought response in the bioenergy crop sugarcane (Saccharum spp.). PLoS One 7:e46703.

Gentile A, Ferreira TH, Mattos RS, Dias LI, Hoshino AA, Carneiro MS, Souza GM, Calsa Jr. T, Nogueira RM, Endres L, Menossi M (2013) Effects of drought on the microtranscriptome of fieldgrown sugarcane plants. Planta 237:783-798.

Gonçalves ER, Ferreira VM, Silva JV, Endres L, Barbosa TP, Duarte WG (2010) Gas exchange and chlorophyll a fluorescence of sugarcane varieties submitted to water stress. Revista Brasileira de Engenharia Agrícola e Ambiental 14:378-386.

Graça JP, Godrigues FA, Farias JRB, Oliveira MCN, Hoffmann-Campo CB, Zingaretti SM (2010) Physiological parameters in sugarcane cultivars submitted to water deficit. Brazilian Journal of Plant Physiology 22:189-197.

Guimarães ER, Mutton MA, Mutton MJR, Ferro MIT, Ravaneli GC Silva JA (2008) Free proline accumulation in sugarcane under water restriction and spittlebug infestation. Scientia Agricola 65:628-633.

Hasegawa PM, Bressan RA, Zhu Jian-Kang, Bohnert HJ (2000) Plant cellular and molecular responses to high salinity. Annual Review of Plant Physiology and Plant Molecular Biology 51:463-499.

Hemaprabha G, Nagarajan R, Alarmelu S (2004) Response of sugarcane genotypes to water deficit stress. Sugar Tech 6:165-168.

Hessini K, Martínez JP, Gandoura M, Albouchib A, Soltania A, Abdellya C (2009) Effect of water stress on growth, osmotic adjustment, cell wall elasticity and water-use efficiency in Spartina alterniflora. Environmental and Experimental Botany 67:312-319.
Inman-Bamber NG, Smith DM (2005) Water relations in sugarcane and response to water deficits. Field Crops Research 92:185-202.

Inman-Bamber, NG (2004) Sugarcane water stress criteria for irrigation and drying off. Field Crops Research 89:107-122.

Jangpromma N, Songsri P, Thammasirirak S, Jaisil P (2010) Rapid assessment of chlorophyll content in sugarcane using a SPAD chlorophyll meter across different water stress conditions. Asian Journal of Plant Sciences 9:368-374.

Jaleel CA, Manivannan P, Wahid A, Farooq M, Somasundaram R, Panneerselvam R (2009) Drought stress in plants: a review on morphological characteristics and pigments composition. International Journal of Agriculture and Biology 11:100-105.

Kavi Kishor PB, Sangam S, Amrutha RN, Sri Laxmi P, Naidu KR, Rao KRSS, Sreenath Rao Reddy KJ, Theriappan P, Sreenivasulu N (2005) Regulation of proline biosynthesis, degradation, uptake and transport in higher plants: its implications in plant growth and abiotic stress tolerance. Current Science 88:424-438.

Lawlor DW (2013) Genetic engineering to improve plant performance under drought: physiological evaluation of achievements, limitations, and possibilities. Journal of Experimental Botany 64:83-108.

Larcher, W (2006) Ecofisiologia vegetal. Translation: Prado CHBA. 1 st ed. São Carlos: Rima.

Liberato MAR, Gonçalves JFC, Chevreuil LR, Nina Junior AR, Fernandes AV, Santos Junior UM. 2006. Leaf water potential, gas exchange and chlorophyll a fluorescence in acariquara seedlings (Minquartia guianensis Aubl.) under water stress and recovery. Brazilian Journal of Plant Physiology 18:315-323.

Lichtenthaler HK, Buschmann C (2001) Chlorophylls and carotenoids - Measurement and characterisation by UV-VIS. In: Current protocols in food analytical chemistry. Madison: John Wiley \& Sons. F4.3.1-F4.3.8.

Medeiros DB, Silva EC, Santos HRB, Pacheco CM, Musser RS, Nogueira RJMC (2012) Physiological and biochemical response to drought stress in the Barbados cherry. Brazilian Journal of Plant Physiology 24:181-192.

Nogueira RJMC, Moraes JAPV, Burity HA (2000) Modifications in vapor diffusion resistence of leaves and water relations in barbados cherry plants under water stress. Pesquisa Agropecuária Brasileira 35:1331-1342.

Nogueira RJMC, Moraes JAPV, Burity HÁ, Bezerra Neto E (2001) Modifications in vapor diffusion resistance of leaves and water relations in Barbados cherry plants under water stress. Revista Brasileira de Fisiologia Vegetal 13:75-87.

Pimentel C (1999) Gas exchange and chlorophyll a fluorescence of sugarcane varieties submitted to water stress. Pesquisa Agropecuária Brasileira 34:2021-2027.

Queiroz RJB, Santos DMM, Carlin SD, Marin A, Banzatto DA, Cazetta JO (2008) Effects of osmoprotectors on sugarcane plants growing under different water deficit levels. Científica 36:107-115. 
Scholander PF, Hammel HT, Hemingsen EA, Bradstreet ED (1964) Hydrostatic pressure and osmotic potentials in leaves of mangroves and some other plants. Proceeding of the National Academy of Science 52:119-125.

Silva EC, Albuquerque MB, Azevedo Neto AD, Silva Junior $C D$ (2013) Drought and its consequences to plants from individual to ecosystem. In: Şener Akıncı, editor. Responses of organisms to water stress. Croatia: InTech. pp.17-47.

Silva EC, Nogueira RJMC, Vale FHA, Melo NF, Araujo FP (2009) Water relations and organic solutes production in four umbu tree (Spondias tuberosa) genotypes under intermittent drought. Brazilian Journal of Plant Physiology 21:43-53.

Silva EC, Silva MFA, Nogueira RJMC, Albuquerque MB (2010) Growth evaluation and water relations of Erythrina velutina seedlings in response to drought stress. Brazilian Journal of Plant Physiology 22:225-233.

Silva MA, Jifon JL, Silva JAG, Sharma V (2007) Use of physiological parameters as fast tools to screen for drought tolerance in sugarcane. Brazilian Journal of Plant Physiology 19:193-201.
Simões Neto DE, Melo LJOT, Chaves A, Lima ROR (2005) Levantamento de novas variedades RB de cana-de-açúcar. Boletim técnico 1. Recife: UFRPE, Imprensa Universitária. 28p.

Sircelj H, Tausz M, Grill D, Batic F (2005) Biochemical responses in leaves of two apple tree cultivars subjected to progressing drought. Journal of Plant Physiology 162:1308-1318.

Souza CC, Oliveira FA, Silva IF, Amorim Neto MS (2000) Evaluation of methods of available water determination and irrigation management in 'terra roxa' under cotton crop. Revista. Brasileira de Engenharia Agrícola e Ambiental 4:338-342.

Souza RP, Machado EC, Silva JAB, Lagôa AMMA, Silveira JAG (2004) Photosynthetic gas exchange in cowpea (Vigna unguiculata) during water stress and recovery. Environmental and Experimental Botany 51:45-56.

Yemm EW, Cocking EC (1955) The determination of aminoacids by ninhydrin. Analyst $80: 209-213$. 